\title{
THE EFFECTS OF MICRONUTRIENTS (Fe and Zn) AND BENEFICIAL NANO-SCALED ELEMENTS (Si and Ti) ON SOME MORPHO- PHYSIOLOGICAL CHARACTERISTICS OF OILSEED RAPE HYBRIDS
}

\author{
MOHSEN KHEYRKHAH, MOHSEN JANMOHAMMADI*, AMIN ABBASI, \\ NASER SABAGHNIA
}

University of Maragheh, Iran

KHEYRKHAH, M. - JANMOHAMMADI, M. - ABBASI, A. - SABAGHNIA, N.: The effect of micronutrients (Fe and $\mathrm{Zn}$ ) and beneficial nano-scaled elements ( $\mathrm{Si}$ and $\mathrm{Ti}$ ) on some morpho-physiological characteristics of oilseed rape hybrids. Agriculture (Pol'nohospodárstvo), vol. 64, 2018, no. 3, pp. 116-127.

\begin{abstract}
Current experiment was conducted to investigate the effects of foliar application of different nutrients (control, nano-chelated $\mathrm{Fe}$, nano-chelated $\mathrm{Zn}$, nano- $\mathrm{TiO}_{2}$, nano-Si) on seed yield and morpho-physiological characteristics of oilseed rape cultivars (Hydromel, Neptune, Nathalie, Danube, Alonso). The highest pod numbers was achieved by foliar application of $\mathrm{Zn}$ and nano- $\mathrm{SiO}_{2}$ in cv. Hydromel and Neptune. The heaviest seeds were recorded for plants treated with nano-SiO ${ }_{2}$. The highest seed yield was recorded for cv. Hydromel and Neptune treated with $\mathrm{Fe}$ and nano- $\mathrm{TiO}_{2}$. The highest indole acetic acid was recorded in cv. Hydromel treated with $\mathrm{Zn}$ and nano- $\mathrm{SiO}_{2}$. The evaluation of plant pigments revealed that foliar application of nano- $\mathrm{SiO}_{2}$ and $\mathrm{TiO}_{2}$ significantly increased the concentration of carotenoids and Chlorophyll a, b. Overall, the results indicate that cultivating the high yielding hybrids (Hydromel, Neptune, Nathalie) along with the application of iron, $\mathrm{SiO}_{2}$ and $\mathrm{TiO}_{2}$ nano-particles can greatly improve plant performance.
\end{abstract}

Key words: hybrids cultivars, iron, malondialdehyde, nano-particles, zinc

Rapeseed (Brassica napus L.) is one of the most important oilseed plants which its small seeds containing more than $40 \%$ oil, and its meal has the same protein content (Wanasundara et al. 2016). The economic significance of Brassica oil seed crops can be attributed to their role in global food security. In recent decades rape has been cultivated in the throughout world and its production is ranked third among the major oil crop (Thiyam-Holländer et al. 2012). Rapeseed oil has high nutritional quality due to its unsaturated fatty acids and absence of cholesterol. Likewise, great volumes are need for processing oil into biofuels as a renewable energy source that highlight the request for the oil crop. In the last decade, the area under rapeseed cultivation increased at the rate of 1 million ha/year around the world to reached around 34 million ha in 2016 growing season and the average seed production was about 69 million tons (FAOSTAT 2018). However, the cultivated area of rapeseed in Iran is about 75,000 hectares and the amount of grain production in these lands is about 139,000 tons. The comparison of the average yield in Iran with the global average indicated that rapeseed production in Iran is subject to some restrictions. Altogether, the introduction of a combinable broadleaved crop in crop rotation instead of a cereal monoculture can increase yields of winter wheat by up to $10 \%$ (Sieling \& Christen 2015). However, the oil content in different canola cultivars are significantly variable and there is also a great variation in the composition of fatty acids. On the other hand it have been recognized that oil content and quality are considerably affected by environmental conditions and agronomic management. Between agricultural

Eng. Mohsen Kheyrkhah, Dr. Mohsen Janmohammadi (*Corresponding author), Dr. Amin Abbasi, Dr. Naser Sabaghnia, Department of Plant Production and Genetics, Agriculture College, University of Maragheh, P.O. Box 55181-83111, Iran. E-mail: jmohamad@alumni.ut.ac.ir 
management, plant nutrition has an important effect on the quantity and quality of rapeseed.

Balanced nutrient managements and soil enrichment are very important management for improving crop productivity (Danilovič \& Šoltysová 2010; Šoltysová \& Danilovič 2011). Although micronutrients are required in very low amount for plant, their role is very important and exclusive. Zinc and iron are essential for plant growth and they are involved in physiological processes such as photosynthesis, production of phyto-hormones and chlorophyll formation. Deficiency of micronutrients can cause some substantial nutrient imbalances in the plant, and ultimately reduce the quantity and quality of the crop product (Marschner 2011). Semiarid regions are faced with some restrictions such as unfavorable climatic condition, highly alkaline soils, bicarbonate content of the irrigation water, low organic matter, and excessive application of the phosphate fertilisers. These factors lead to severe micronutrient, especially zinc and iron, deficiencies in the soil (Tadayyon et al. 2017). In soil with micronutrient deficiency or in semi-arid region with relatively dry surface soil, the spraying of these elements in rapeseed plant should be used early in the vegetative growth stage, which increases grain yield and oil percent. It has been reported that zinc increases the number of pods per plant, grain yield, and oil percent (Ravi et al. 2008). Fe plays imperative role in metabolic processes such as DNA synthesis, respiration, and photosynthesis, and it is also involved in electron transport chain, synthesis of chlorophyll, maintenance of chloroplast structure, redox balance and ROS scavenging (Rout \& Sahoo 2015).

In recent years, the application of some effective nanoparticles in agriculture has become widespread. There has been a special focus on $\mathrm{SiO}_{2}$ and $\mathrm{TiO}_{2}$ nano-particles. Although silicon is abundant in the soil, but its absorbable form is very low. From the last two decades there is growing evidence that show silicon nanoparticles can be introduced as one of the elite compounds for the enhancement of agricultural yields (Ma et al. 2001; Ma 2004; Ma \& Yamaji 2006; Zhang \& Fang 2010; Gerami \& Rameeh 2012; Van Bockhaven et al. 2013; Zhu \& Gong 2014; Coskun et al. 2016; Sun et al. 2016; Janmohammadi et al. 2017). Silicon (Si) has not been proven to be an essential element for higher plants, but its beneficial effects on growth have been reported in a wide variety of crops, including rice, wheat, barley, and cucumber (Ma et al. 2001). Beneficial roles of $\mathrm{Si}$ in mitigating the biotic and abiotic stresses appeared by inducing defense mechanisms (Van Bockhaven et al. 2013; Zhu \& Gong 2014). Silicon nanoparticles have irregular shapes and they are non-crystalline solids. Their distinct properties such as nontoxic, large surface area, and especial physicochemical properties is the result from their size and shape characteristics.

In an experiment, nano- $\mathrm{TiO}_{2}$ and $\mathrm{SiO}_{2}$ enhance the nitrate reductase activity in soybeans to strengthen plant absorption ability (Lu et al. 2002). The beneficial effects of nano- $\mathrm{TiO}_{2}$ were considered on germination of deteriorated seeds and vegetative growth. It was indicated that the biological effects are dependent on the size of particles and the applied concentration (Gholami-Shabani et al. 2017).

Exogenous application of nano- $\mathrm{TiO}_{2}$ can facilitate the production of pigments and transformation of light energy to active electron and chemical activity, thereby increasing photosynthetic efficiency and affecting the light harvesting complex (Lei et al. 2007). These promote energy transfer and oxygen evolution in photosystem II of spinach (Lei et al. 2007). It was found that, mineral form nano- $\mathrm{TiO}_{2}$ promotes antioxidant stress by decreasing the accumulation of superoxide radicals, hydrogen peroxide, and malonyldialdehyde content while enhancing the activities of superoxide dismutase, catalase (ascorbate peroxidase), and guaiacol peroxidase, thereby increasing the evolution oxygen rate in spinach chloroplasts under UV-B radiation (Lei et al. 2008). However, these effects vary from plant to plant, and require more detailed and comprehensive studies. Due to the extensive cultivation of rapeseeds in northwest of Iran and other parts of the world and in view of the potential effect of nano- $\mathrm{TiO}_{2}$ on its growth, this plant can be selected as the model system. Already the positive effect of $\mathrm{TiO}_{2}$ on germination of rapeseed (Brassica napus) was reported by Mahmoodzadeh et al. (2013). In this present study, the effects of nano- $\mathrm{SiO}_{2}$, nano- $\mathrm{TiO}_{2}, \mathrm{Fe}$ and, $\mathrm{Zn}$, on the seed yield and physiological parameters in rapeseed were examined. 


\section{MATERIAL AND METHODS}

\section{Site of study}

The field trial was carried at Qazvin province, Iran $\left(36^{\circ} 08^{\prime} \mathrm{N}, 4^{\circ} 85^{\prime} \mathrm{E}\right)$ during the 2016-2017 growing season. The yearly average of precipitation (30 years long-term period) was $301 \mathrm{~mm}$ that typically concentrated during the autumn and winter months (November to February). In August, precipitation was at its lowest, with an average of $1 \mathrm{~mm}$. The greatest amount of precipitation occurred in April, with an average of $75 \mathrm{~mm}$. The climate of location based on Köppen climate classification is BSK; semi-arid moderate (Peel et al. 2007). Soil samples $(0-30 \mathrm{~cm})$ were collected at sowing and analysed for some physic-chemical properties. The soil texture of the studied area was clay loam with $0.31 \%$ organic matter content and $\mathrm{pH}$ of 7.6. Total $\mathrm{N}$ content was $0.04 \%$, available $\mathrm{P}$ was $9.13 \mathrm{mg} / \mathrm{kg}$, available $\mathrm{K}$ was $121.0 \mathrm{mg} / \mathrm{kg}$, available $\mathrm{Fe}$ was 1.71 $\mathrm{mg} / \mathrm{kg}$, available $\mathrm{Zn}$ was $0.58 \mathrm{mg} / \mathrm{kg}$ and available Mn was $2.28 \mathrm{mg} / \mathrm{kg}$.

The previous crop was winter barley and sowing was done with hand during the $4^{\text {rd }}$ week of September in $3 \mathrm{~cm}$ depth. Prior to sowing, the field was thoroughly ploughed to ensure adequate soil aeration. The field was irrigated prior to sowing to maintain proper moisture content in the subsurface of the soil. The size of plots was $4 \times 4$ and there was eightrow in each plot, $4 \mathrm{~m}$ long with spacing of $0.5 \mathrm{~m}$ between rows, and at a rate of 20 seeds per meter of row. The field was irrigated immediately after planting and thinned at the rosette stage. A small terraces of $1.5 \mathrm{~m}$ considered in the interspaces to prevent contamination by surface run-off containing fertiliser. There was no incidence of pest or disease on plants during the experiment. The crop was kept free of weeds by hand hoeing for 6,8 or 10 weeks after crop emergence. The experiment was laid out according to a factorial randomized block design $(5 \times 5)$ and was replicated three times. The first factor was foliar treatment included control (check; no traetment), nano-chelated $\mathrm{Fe}(2,000 \mathrm{ppm})$, nano-chelated $\mathrm{Zn}(2,000 \mathrm{ppm})$, nano-Ti (20 ppm), nano-Si $(20 \mathrm{ppm})$. The concentrations were selected according to the results of previous experiments in the region (Janmohammadi et al. 2016; Janmohammadi et al. 2017). The consumption rate was $100 \mathrm{cc} / \mathrm{m}^{2}$. Nano-chelated micronutrient fertilisers purchased from Fanavar Sepehr Parmans Co. Iran. They contained nanoparticles of iron or zinc oxide chelated by ethylenediaminetetraacetic acid (EDTA). Nanoparticles of $\mathrm{SiO}_{2}$ and $\mathrm{TiO}_{2}$ were purchased from the Pishgaman Nano, Iran. According to the manufacturer, the particle sizes of $\mathrm{SiO}_{2}$ ranged from 20 to $100 \mathrm{~nm}$. Synthesized nano-particles had been characterized morphologically by transmission electron microscopy. Specific surface area of nano-sized practices was $180-600 \mathrm{~m}^{2} / \mathrm{g}$ and purity was $99.7 \%$. The foliar treatment was applied three times during the vegetative and reproductive growth stage (BBCH 23; 3 side shoots detectable, $\mathrm{BBCH}$ 36 ; stem elongation, $\mathrm{BBCH} 55$; inflorescence emergence). The second factor was rapeseed cultivars. The winter hybrid cultivars used in the study were Hydromel, Neptune, Nathalie, Danube, Alonso. All hybrid were originated from France. Cultivar selection was based on yield performance from earlier trials.

\section{Measurement of chlorophyll concentration}

Newly full expanded leaves were collected from plants for biochemical analysis at initiation of seed development stage (BBCH 70; pods formation). The concentration of chlorophyll a and b measured using a spectrophotometer according to Dere et al. (1998). For this purpose $100 \mathrm{mg}$ of fresh fully expanded leaf was collected from upper part of shoot and extracted with $99 \%$ methanol and read absorption recorded using spectrophotometer at 653 and $666 \mathrm{~nm}$ wavelengths, for chlorophyll a and b, respectively. Chlorophyll concentrations were estimated according blow equations: $\mathrm{Chl}-\mathrm{a}=15.65 \mathrm{~A} 666-7.340 \mathrm{~A} 653$; Chl-b $=27.05$ A653 - 11.21 A666. Total carotenoids were estimated according 1000 A470 - 2.860 Chl-a $-129.2 \mathrm{Chl}-\mathrm{b} / 245$.

\section{Measurement of malondialdehyde}

Malondialdehyde (MDA) is one of the most commonly reported biomarkers of lipid peroxidation. MDA content was estimated in shoots as described by Heath \& Packer (1968) through a colorimetric method. Shoot samples were homogenized in $2 \mathrm{ml}$ of $0.1 \%$ trichloroacetic acid (TCA) and centrifuged. Then, $0.5 \mathrm{ml}$ of supernatant was mixed with $2 \mathrm{ml}$ of $20 \%$ TCA containing $0.5 \%$ thiobarbituric acid. The mixture was incubated at $95^{\circ} \mathrm{C}$ for $30 \mathrm{~min}$. The sam- 
ples were centrifuged at $10,000 \mathrm{rpm}$ for $10 \mathrm{~min}$. The absorbance of the supernatant was read at 532 and $600 \mathrm{~nm}$. The amount of MDA was calculated from the extinction coefficient of $155 \mathrm{Mm} / \mathrm{cm}$.

\section{Quantitation of sugar, proline and indole acetic acid}

Total amount of sugar was determined by phenol-sulfuric acid method (Dubois et al. 1956). Their concentration in the extract was determined at $490 \mathrm{~nm}$ in a spectrophotometer, using glucose as the standard. Proline content was determined according to the method of Bates et al. (1973). Dai et al. (2009) procedure was followed to determine $\mathrm{H}_{2} \mathrm{O}_{2}$ content of the supernatant. The extraction and assessment of 3-indole acetic acid was conducted according to Sheikhian \& Bina (2016).

\section{Evaluation of yield components}

At maturity stage most of the leaves were turn a brown color and very little green remained on the latest emerged pods. Plants were harvested at ground level by hand from late July to early August. Data on growth characteristics and yield components were recorded on fifteen plants randomly selected from the three middle rows. The evaluated agronomic traits included length of pod, number of seed per pod, stem diameter, seeds numbers per plants, thousand seeds weight. Plant height was evaluated from ground level to the tip of main stem at maturity time. Biological yield was obtained by plant cutting from ground level at maturity stage. Straw yield was calculated by subtracting seed yield from dry matter yield. Harvest index was calculated as the ratio of grain yield to aboveground dry matter at maturity. Depending on the number of factors assessed, data were subjected to analysis of variance using SAS statistical package to assess the effect of treatments and their interactions on the analysed traits. Significant differences between means were then determined using the $L S D$ at $95 \%$ confidence $(P \leq 0.05)$. All applied tests were two-tailed.

\section{RESULTS}

Result of variance analysis showed that foliar treatment considerably affected plant height. The tallest plant was recorded under nano-particles ( $\mathrm{Si}$ and Ti) application condition. However, the appli- cation of micronutrients increased the plant height by $11-13 \%$ over the control (Table 1$)$. Length of the pod as one of the most influential yield component affected by foliar treatment. The longest pod recorded for plant treated by nano- $\mathrm{SiO}_{2}$ and $\mathrm{Fe}$. Also number of seed per pod noticeably responded to foliar treatment so that the highest number of seeds per pod was recorded for Zn-treated plants. Although the application of iron, nano- $\mathrm{SiO}_{2}$ and $\mathrm{TiO}_{2}$ could improve the number of seed per pod by about $9 \%$ compared to the control, the improving of effect zinc application was much more evident and increased this component by $28 \%$. Assessment of pod number per plants showed that reaction of the cultivars to the foliar treatments was very different. The highest pod number was related to cv. Nathalie treated with Fe, cv. Danube treated with Zn, cv. Alonso treated with nano-Ti and cv. Hydromel treat-

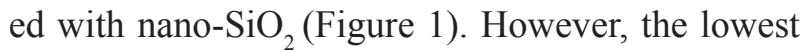
pods number were found in the cv. Natalie, Danube, and Alonso under control conditions.

Evaluation of stem diameter showed that this trait significantly affected by foliar treatment and also there was significant difference between the stem diameter of cultivars. The thickest stem was recorded for plant treated with $\mathrm{Zn}$ and nano- $\mathrm{SiO}_{2}$. Mean comparison between cultivars showed that the thickest stem was recorded for to Hydromel cultivar (Table 1). Valuation of 1,000-seed weight showed that heaviest seed was obtained by foliar application of nano-SiO 2 in cv. Hydromel, Nathalie, Danube and Alonso (Figure 2). Likewise, the application of nano- $\mathrm{TiO}_{2}$ and $\mathrm{Zn}$ in cv. Hydromel and Nathalie also had positive substantial effects on this trait. Evaluation of seed yield showed that all foliar treatments significantly increased seed yield when compared with control. The best performance was recorded for cv. Hydromel treated with $\mathrm{Fe}$ and nano-TiO (Figure $_{2}$ $3)$. The mentioned cultivars showed an acceptable performance by most of the foliar treatments. $\mathrm{Zn}$ and nano-Ti application could significantly improve the seed yield of Alonso cultivar.

Investigation of proline content showed that the highest amount was related to cv. Neptune and Nathalie which treated with nano-Ti and Zn. Assessment of sugar content showed that foliar treatment significantly affected this trait $(P<0.05)$. The highest amount was recorded for plants treat- 
ed with nano- $\mathrm{SiO}_{2}, \mathrm{Fe}$ and nano- $\mathrm{TiO}_{2}$, respectively. The mentioned treatments increased sugar content by $6 \%$. Comparisons of sugar content between cultivars showed that the highest sugar content was related to Alonso, Danube and Nathalie cultivars, respectively.

The study of pigments indicated that the interaction of foliar treatment $\times$ cultivar for these was highly significant components. The highest content of chlorophyll a (chl-a) was recorded in Neptune cultivar using nano-Ti and $\mathrm{Zn}$. Assessment of chlorophyll b (chl-b) showed that the highest content was recorded in Hydromel and Alonso cultivars by foliar application of $\mathrm{Fe}$ and nano-Si. This trend was also observed for carotenoid content (Table 1). Evaluation of hydrogen peroxide $\left(\mathrm{H}_{2} \mathrm{O}_{2}\right)$ content showed that the highest amount was related to untreated plants. The lowest amount of $\mathrm{H}_{2} \mathrm{O}_{2}$ was recoded in cv. Neptune treated with nano-Ti, Fe and Zn (Figure 4). The highest amount of $\mathrm{H}_{2} \mathrm{O}_{2}$ was observed in Hydromel cultivar.
Reactive oxygen species can attack the polyunsaturated fatty acids of membrane lipids causing lipid peroxidation and the disorganization of cell structure and function. MDA is widely used as a biomarker for assessing oxidative stress. Assessment of MDA showed that lowest amount was related to $\mathrm{cv}$. Alonso treated with $\mathrm{Fe}$. The highest level of MDA was observed in the control condition (Figure 5). Although all foliar treatments significantly reduced MDA, this reduction was more pronounced for nano- $\mathrm{SiO}_{2}$.

Measurement of idole acetic acid showed that the highest concentration was related to cv. Hydromel treated with $\mathrm{Zn}$ and cv. Danube treated with nano- $\mathrm{TiO}_{2}$ (Figure 6). Also foliar application of Fe, nano-SiO in cv. Neptune and foliar application of $\mathrm{Fe}$ and $\mathrm{Zn}$ in cv. Nathalie significantly increased the idol acetic acid when compared with control. Cluster analysis of combined treatments based on similarity is shown in Figure 7. Cluster I showed the lowest performance. Cluster II which included cv. Hydromel and foliar application of $\mathrm{Zn}$ and $\mathrm{Fe}$

T a b 1 e 1

Effect of foliar application of different nutrients on morpho-physiological traits of winter oilseed rape (Brassica napus L.) hybrids

\begin{tabular}{|c|c|c|c|c|c|c|c|c|c|}
\hline Treatment & $\mathrm{PH}$ & LP & NSP & SD & Pro & $\mathrm{SU}$ & CHA & $\mathrm{CHB}$ & Car \\
\hline Control (No fertiliser) & $159.26^{\mathrm{c}}$ & $6.07^{\mathrm{bc}}$ & $21.93^{b}$ & $10.86^{\mathrm{b}}$ & $52.10^{\mathrm{d}}$ & $1.37^{\mathrm{b}}$ & $236.39^{e}$ & $120.25^{\mathrm{e}}$ & $234.32^{\mathrm{e}}$ \\
\hline nano-chelated iron & $173.26^{\mathrm{b}}$ & $6.86^{\mathrm{ab}}$ & $23.86^{\mathrm{ab}}$ & $12.55^{\mathrm{ab}}$ & $53.49^{b}$ & $1.36^{\mathrm{b}}$ & $284.64^{\mathrm{d}}$ & $276.90^{\mathrm{a}}$ & $573.39^{b}$ \\
\hline nano-chelated zinc & $178.40^{\mathrm{b}}$ & $6.66^{\mathrm{b}}$ & $27.13^{\mathrm{a}}$ & $14.24^{\mathrm{a}}$ & $52.55^{\mathrm{c}}$ & $1.45^{\mathrm{a}}$ & $313.21^{\mathrm{b}}$ & $217.59^{c}$ & $434.01^{\mathrm{d}}$ \\
\hline nano- titanium & $190.33^{\mathrm{a}}$ & $6.65^{\mathrm{b}}$ & $23.73^{\mathrm{ab}}$ & $12.79^{\mathrm{ab}}$ & $55.99^{a}$ & $1.43^{\mathrm{ab}}$ & $384.93^{\mathrm{a}}$ & $199.37^{\mathrm{d}}$ & $469.91^{\mathrm{c}}$ \\
\hline nano- silicon & $190.46^{\mathrm{a}}$ & $7.14^{\mathrm{a}}$ & $23.80^{\mathrm{ab}}$ & $14.55^{\mathrm{a}}$ & $52.63^{c}$ & $1.45^{\mathrm{a}}$ & $294.56^{c}$ & $255.54^{\mathrm{b}}$ & $655.24^{\mathrm{a}}$ \\
\hline \multicolumn{10}{|l|}{ Cultivars } \\
\hline Hydromel & $183.40^{\mathrm{a}}$ & $6.81^{\mathrm{a}}$ & $24.26^{\mathrm{a}}$ & $15.18^{\mathrm{a}}$ & $51.48^{d}$ & $1.37^{\mathrm{b}}$ & $258.66^{d}$ & $311.42^{\mathrm{a}}$ & $861.18^{\mathrm{a}}$ \\
\hline Neptune & $181.80^{\mathrm{a}}$ & $6.48^{\mathrm{a}}$ & $24.06^{\mathrm{a}}$ & $13.92^{\mathrm{a}}$ & $54.69^{a}$ & $1.39^{\mathrm{ab}}$ & $355.46^{\mathrm{a}}$ & $200.99^{c}$ & $386.69^{c}$ \\
\hline Nathalie & $171.80^{\mathrm{b}}$ & $6.74^{\mathrm{a}}$ & $25.26^{\mathrm{a}}$ & $12.16^{\mathrm{b}}$ & $54.50^{\mathrm{a}}$ & $1.43^{\mathrm{ab}}$ & $277.64^{\mathrm{c}}$ & $208.76^{b}$ & $433.05^{b}$ \\
\hline Danube & $177.80^{\mathrm{ab}}$ & $6.70^{\mathrm{a}}$ & $22.80^{\mathrm{a}}$ & $11.88^{b}$ & $53.81^{b}$ & $1.42^{\mathrm{ab}}$ & $261.36^{d}$ & $139.17^{\mathrm{d}}$ & $259.26^{\mathrm{d}}$ \\
\hline Alonso & $176.93^{\mathrm{ab}}$ & $6.65^{\mathrm{a}}$ & $24.06^{\mathrm{a}}$ & $11.86^{\mathrm{b}}$ & $52.28^{c}$ & $1.46^{\mathrm{a}}$ & $324.64^{\mathrm{b}}$ & $209.31^{b}$ & $426.69^{b}$ \\
\hline \multicolumn{10}{|l|}{ Level of significance } \\
\hline $\mathrm{T}$ & + & ++ & + & + & + & + & ++ & ++ & ++ \\
\hline $\mathrm{C}$ & $\mathrm{Ns}$ & Ns & Ns & + & ++ & + & ++ & ++ & ++ \\
\hline $\mathrm{T} \times \mathrm{C}$ & Ns & Ns & $\mathrm{Ns}$ & $\mathrm{Ns}$ & + & $\mathrm{Ns}$ & ++ & ++ & ++ \\
\hline
\end{tabular}

$\mathrm{PH}$ - plant height [cm]; LP - length of pod [cm]; NSP - number of seed per pod; SD - stem diameter [cm]; Pro - proline content $[\mathrm{mM}] ; \mathrm{SU}$ - sugar content $[\mu \mathrm{mol} / \mathrm{g} \mathrm{FW}]$; CHA - chlorophyll a concentration [mmol/g FW]; CHB - chlorophyll b concentration $[\mathrm{mmol} / \mathrm{g} \mathrm{FW}$; Car - carotenoid concentration [mmol/g FW]. LSD - Least Significant Difference at $P \leq 0.05$. In each column, values with similar letter(s) are not significantly different at the 5\% level of probability. Ns - Not significant, +- Significant at 5\% level of probability, ++ - Significant at 1\% level of probability. 
had significant effect some morpho-physiological traits. However, they have not considerable effect on the physiological characteristics and measured metabolites and may affect the yield through other mechanisms. Cluster III included different foliar treatments for cv. Neptun and Alonso that in terms of the efficiency of the studied traits, they were in the middle classes. Cluster IV included compounds that had the most effect on physiological properties. The effect of Si was more prominent for cv. Alonso, Nathali, Neptune and Hydromel.

\section{DISCUSSION}

The results showed that all foliar application of nano-particles and micronutrients improved the yield components. However, the effect of $\mathrm{Fe}$ and Si was more pronounced than other treatments. These results may indicate the serious deficiency of micronutrient especially $\mathrm{Fe}$ in studied location. The main reason for the micronutrients deficiencies in these areas is due to the following: low precipi- tation, low soil moisture, high soil $\mathrm{pH}$, calcareous soils, antagonistic effects between the elements in soil, low soil organic matter, successive cultivation and inaccurate soil tillage. In such a situation, the foliar application of micronutrients is the best nutritional method. However, the long-term sustainability of many existing cropping systems in arid and semi-arid environments is questionable because of very low return of organic matter to the soil and high decomposition rate of organic matter that can lead to very low organic matter contents in soils. Therefore, large annual rates of organic inputs are required to sustain an adequate labile soil organic matter pool in cultivated area.

Results of this study showed that foliar application nano-fertilisers and nano beneficial particles significantly affected seed yield which corroborate the findings of a great deal of our previous work on barley under supplemental irrigation in semi-arid region (Janmohammadi et al. 2016). The results of cluster analysis revealed that the effects of foliar treatments were different on cultivars. For newly introduced hybrids, it is necessary to assess the

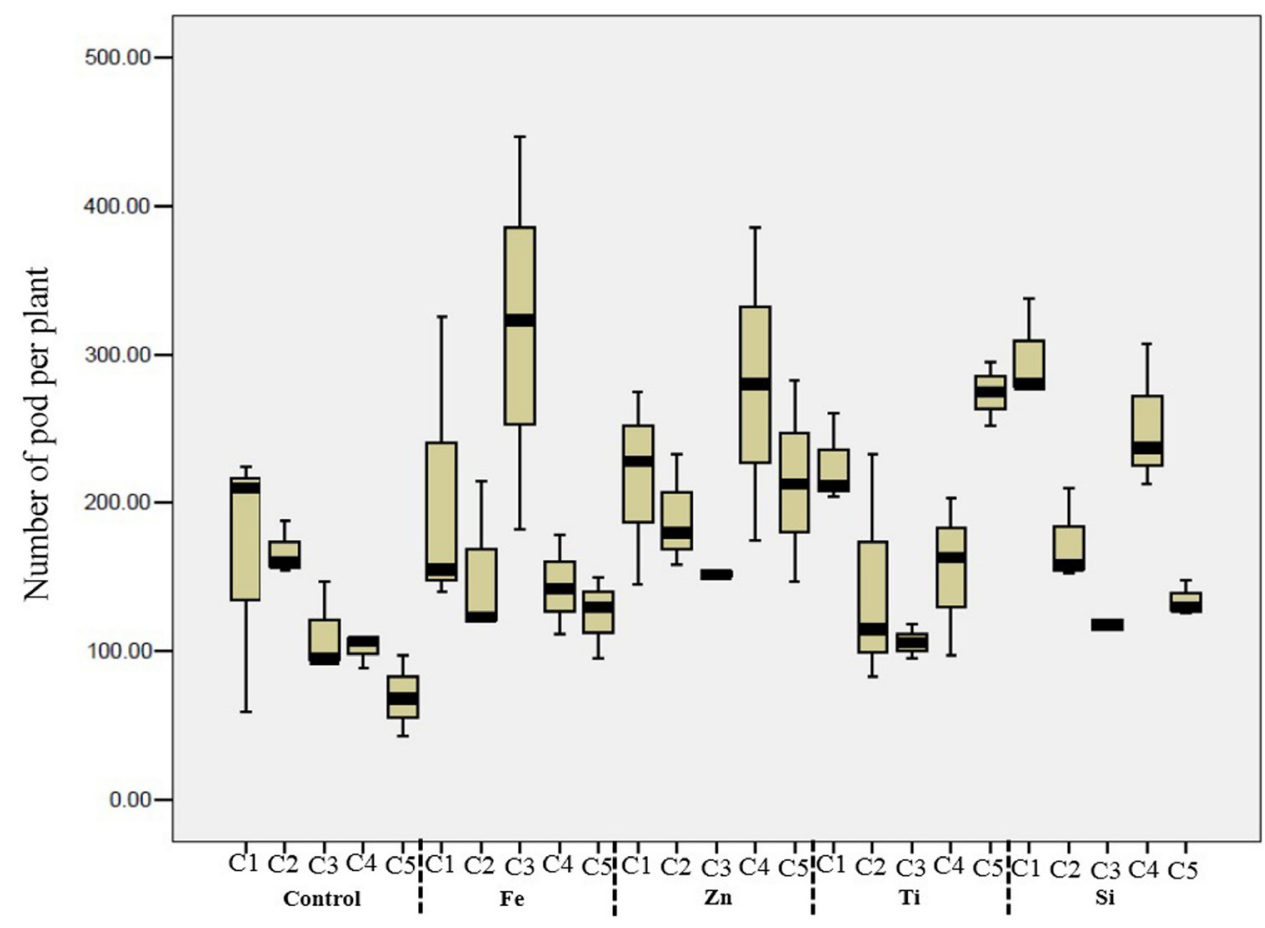

Figure 1. The effects of micronutrient and beneficial nano-particles on number of the pod per plant in different rapeseed hybrids. Control: without application of nano-particles and micronutrients. C1: Hydromel, C2: Neptune, C3: Nathalie, C4: Danube, C5: Alonso. The vertical bar on columns are standard error (SE). The bold horizontal line on columns are average points. The non-overlapping columns are not statistically different at $5 \%$ level of probability. 


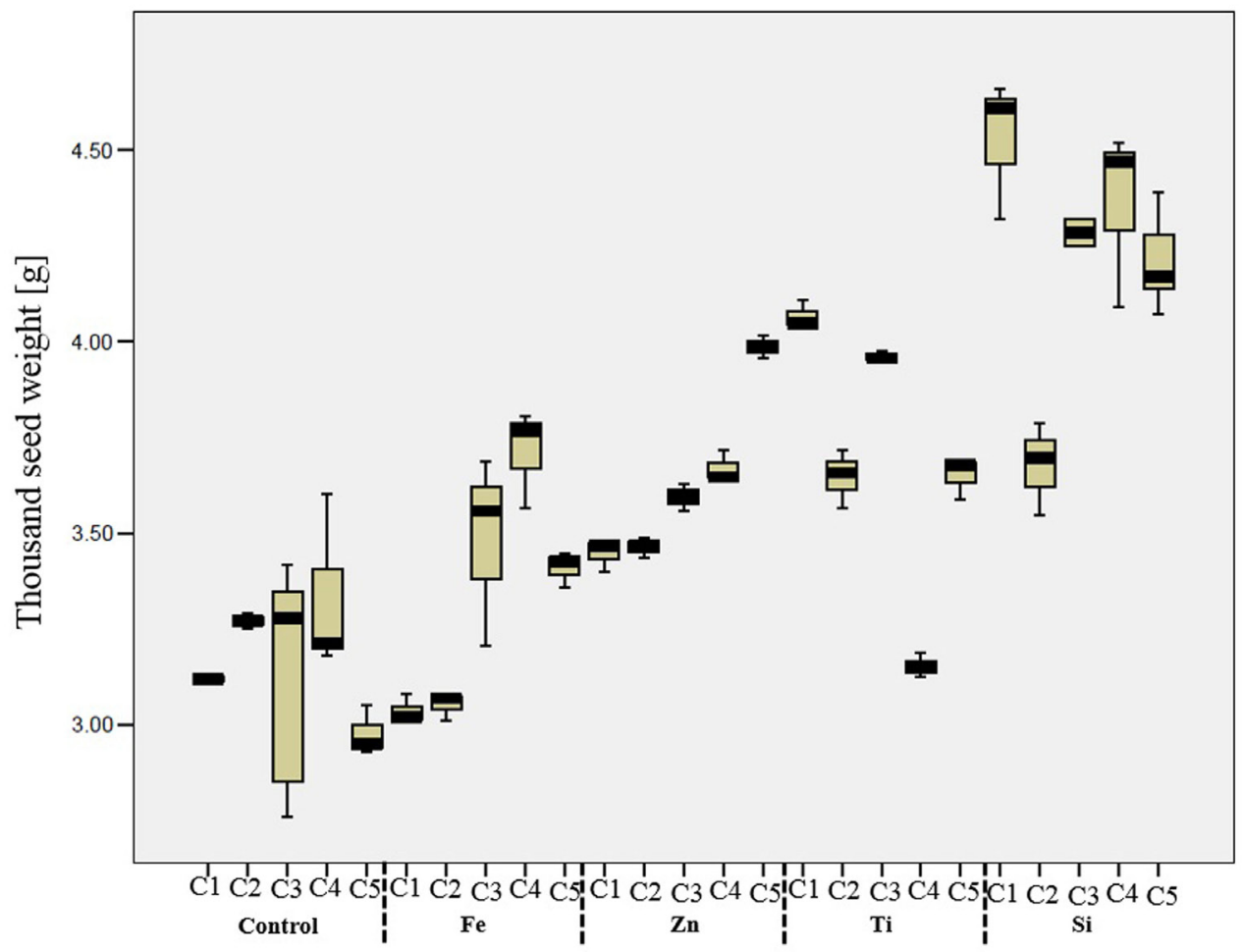

Figure 2. The impact of micronutrient and beneficial nano-particles on 1,000-seed weight of different rapeseed hybrids. Control: without application of nano-particles and micronutrients. C1: Hydromel, C2: Neptune, C3: Nathalie, C4: Danube, C5: Alonso. The vertical bar on columns are standard error (SE). The bold horizontal line on columns are average points.

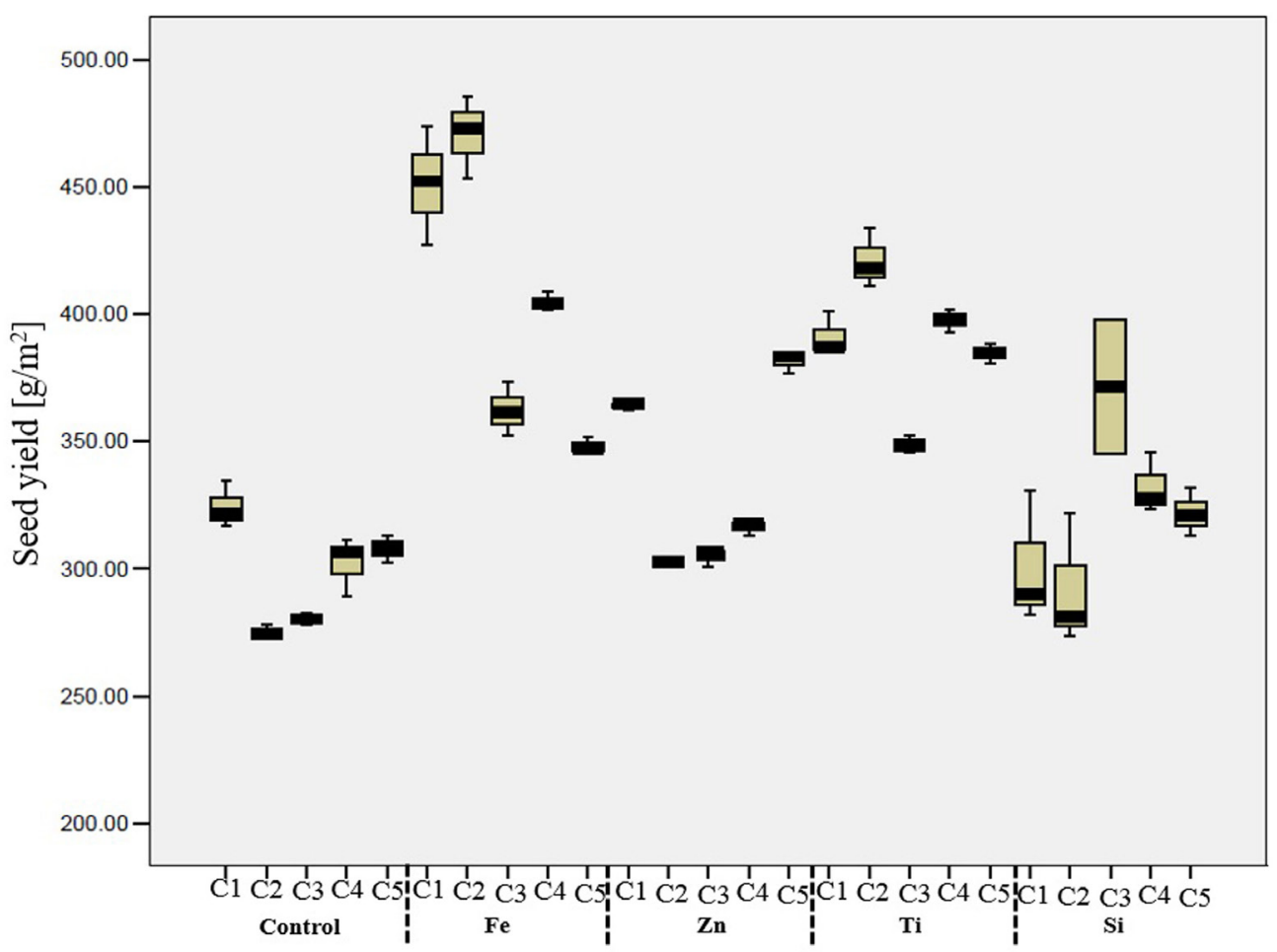

Figure 3. The effect of micronutrient and beneficial nano-particles on seed yield of different rapeseed cultivars. Control: without application of nano-particles and micronutrients. C1: Hydromel, C2: Neptune, C3: Nathalie, C4: Danube, C5: Alonso. The vertical bar on columns are standard error (SE). The bold horizontal line on columns are average points. 
appropriate production technology for different environments. Amongst many others, the nutritional requirements of the crop are considered to be the most important factor. Also, it has been revealed that the use of some nanoparticles could improve the plant performance by increasing defense capacity (antioxidant capacity) and accelerating the growth process by improving chlorophyll content and photosynthetic capacity of source (Mohammadi et al. 2016). In this study the pigments content affect by foliar treatments. However, in this regards Lukas et al. (2014) reported that the relationships between crop parameters and chlorophyll meter readings are not generalisable and thus the interpretation of N-Tester results has to be done separately for each field. Numerous roles have been proposed for anthocyanins induced during abiotic stresses including functioning as reactive oxygen species (ROS) scavengers, photoprotectants, and stress tolerance. Our resulted also showed that proline content was considerably affected by foliar treatments. Proline can intervenes in the prevention of oxygen radical production or it can act as scavenger of ROS and other free radicals (Liang et al. 2013).
There was a significant positive effect of nano-Ti and $\mathrm{Fe}$ on chlorophyll and carotenoids. Chlorophyll is essential for photosynthesis. It serves two primary functions in the photo systems. The major function of chlorophyll is to absorb light and transfer that light energy into chemical energy. Chl-a is the pigment that interacts directly in the light requiring reactions of photosynthesis. Chlorophyll b or Chl-b is different from Chl-a in only one of the functional groups bonded to the porphyrin. It is an accessory pigment and acts indirectly in photosynthesis by transferring light it absorbs to Chl-a. This finding is in agreement with Gao et al. (2008) findings which showed exogenous application of nano-Ti during spinach growth stage promoted chlorophyll formation, Rubisco activase activity and photosynthetic rate which finally lead to increase in plant dry mass. Sugars, which are produced by the plant during photosynthesis process, are a necessary component of plant growth. The photosynthetic active organs that supply sugars for the rest of the plant are called the sources. Source organ export carbon skeletons to sink. The "sink" as one requiring import of carbon, the "sink strength" as the ability of a tissue or an

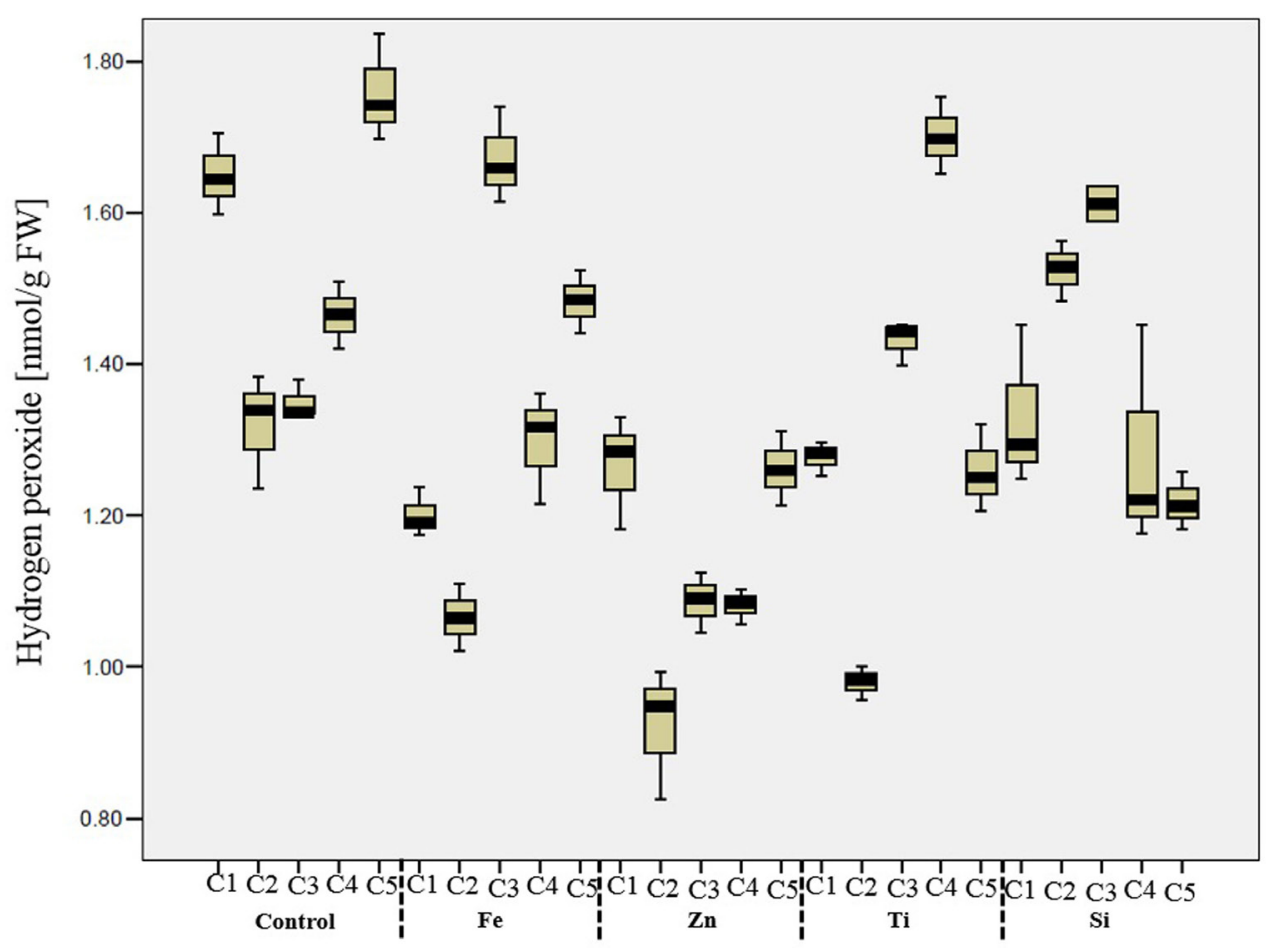

Figure 4. The impact of micronutrient and beneficial nano-particles on content of $\mathrm{H}_{2} \mathrm{O}_{2}$ in different rapeseed hybrids. Control: without application of nano-particles and micronutrients. C1: Hydromel, C2: Neptune, C3: Nathalie, C4: Danube, C5: Alonso. The vertical bar on columns are standard error (SE). The bold horizontal line on culmens are average points. 


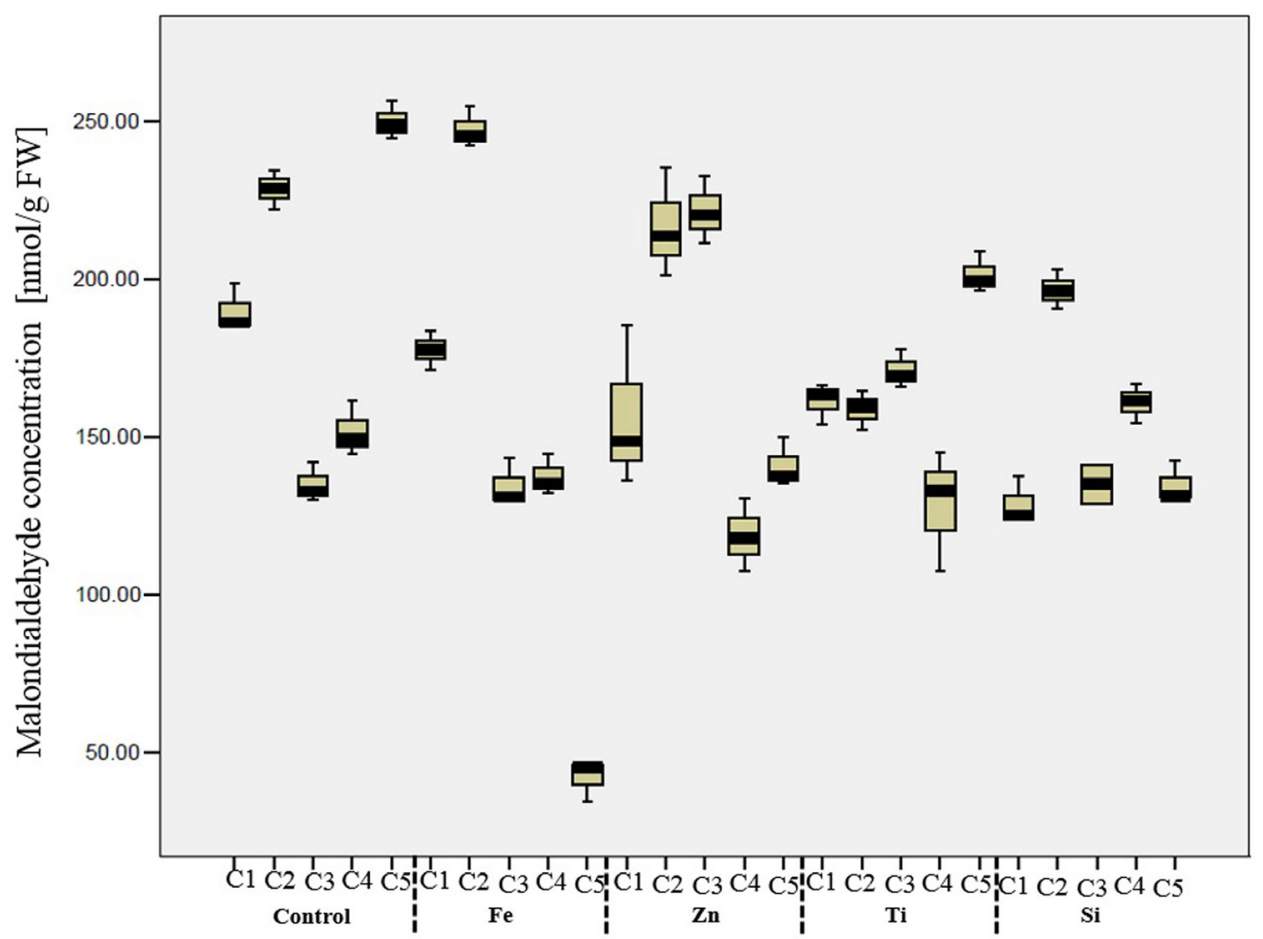

Figure 5. The effect of micronutrient and beneficial nano-particles on concentration of malondialdehyde in different rapeseed hybrids. Control: without application of nano-particles and micronutrients. C1: Hydromel, C2: Neptune, C3: Nathalie, C4: Danube, C5: Alonso. The vertical bar on columns are standard error (SE). The bold horizontal line on columns are average points.

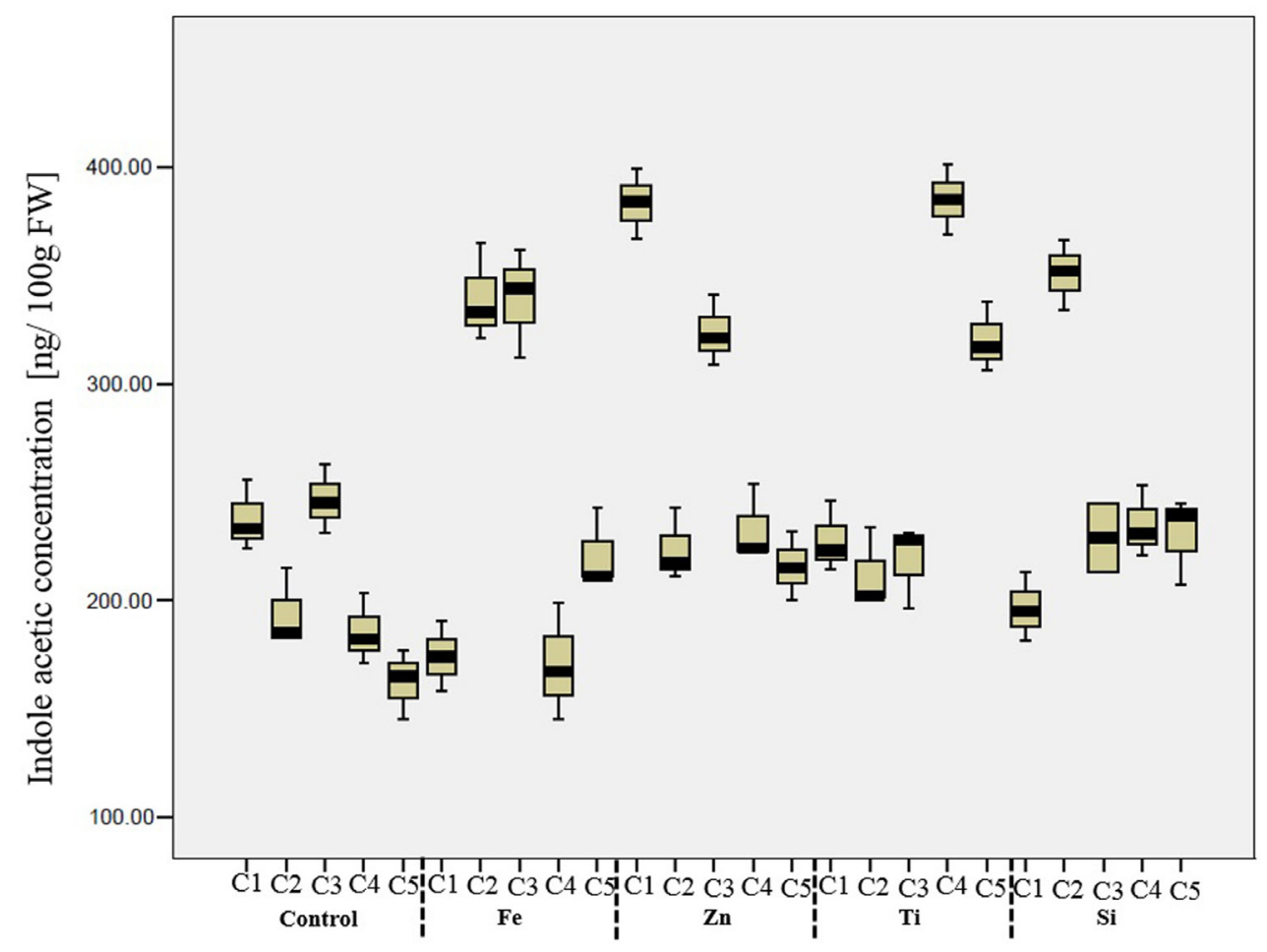

Figure 6. The effect of micronutrient and beneficial nano-particles on content of Indole-3-acetic acid (IAA) in different rapeseed cultivars. Control: without application of nano-particles and micronutrients. C1: Hydromel, C2: Neptune, C3: Nathalie, C4: Danube, C5: Alonso. The vertical bar on columns are standard error (SE). The bold horizontal line on columns are average points. 
organ to mobilize photo-assimilates, the "sink capacity (or sink size)" as the capacity of a tissue or organ to import and store further compounds from the source(s) and the "sink activity" by the rate of respiration. On the other hand, the results indicated that the use of micronutrients and nano- $\mathrm{SiO}_{2}$ can increase some of the performance components, such as the number of seeds per pod, which means increasing the size of the reservoir. Altogether, results showed that application of micronutrients and nano-particles could affect the source-sink relationship. This finding corroborates the ideas of Paul \& Foyer (2001), who suggested that the source-sink relationship determines crop yield, and it is largely regulated nutrients moments.

In addition, our results showed that lipid peroxidation, membrane integrity and active and destructive oxygen species affected by foliar application of micronutrients and nanoparticles. Therefore, part of the increase in plant performance can be due to the strengthening of defense system sand scavenging of reactive oxygen species. The findings of the current study are consistent with those of Wang et al. (2015) who found that nano-Si application alleviated abio- tic stress by decreasing MDA level and by increasing content of some mineral elements (Mg, Fe, and $\mathrm{Zn}$ ) and antioxidant capacity. Also MDA reduction in this study after foliar application of nano- $\mathrm{TiO}_{2}$ are in agreement with earlier findings of Mohammadi et al. (2016).

Investigating the content of sugar, proline, indoleacetic acid showed that foliar treatment affects a very large number of intracellular processes that eventually result in improved performance. Although it has already been shown that the exogenous application of nanoparticles affects some metabolic pathways (Ma 2004; Lei et al. 2008; Zhang \& Fang 2010; Zhu \& Gong 2014; Mohammadi et al. 2016), our work is one of the few experiments that showed that nano- $\mathrm{TiO}_{2}$ and nano- $\mathrm{SiO}_{2}$ can stimulate growth by stimulating the auxin phytohormone.

Although the "green revolution" could remarkably improve crop production through applying the modern agricultural technologies, with irrigation and heavy doses of chemical fertiliser in some regions, the arid and semi-arid areas have not significantly profited from the "green revolution" as much as regions that have sufficient precipitation. For this

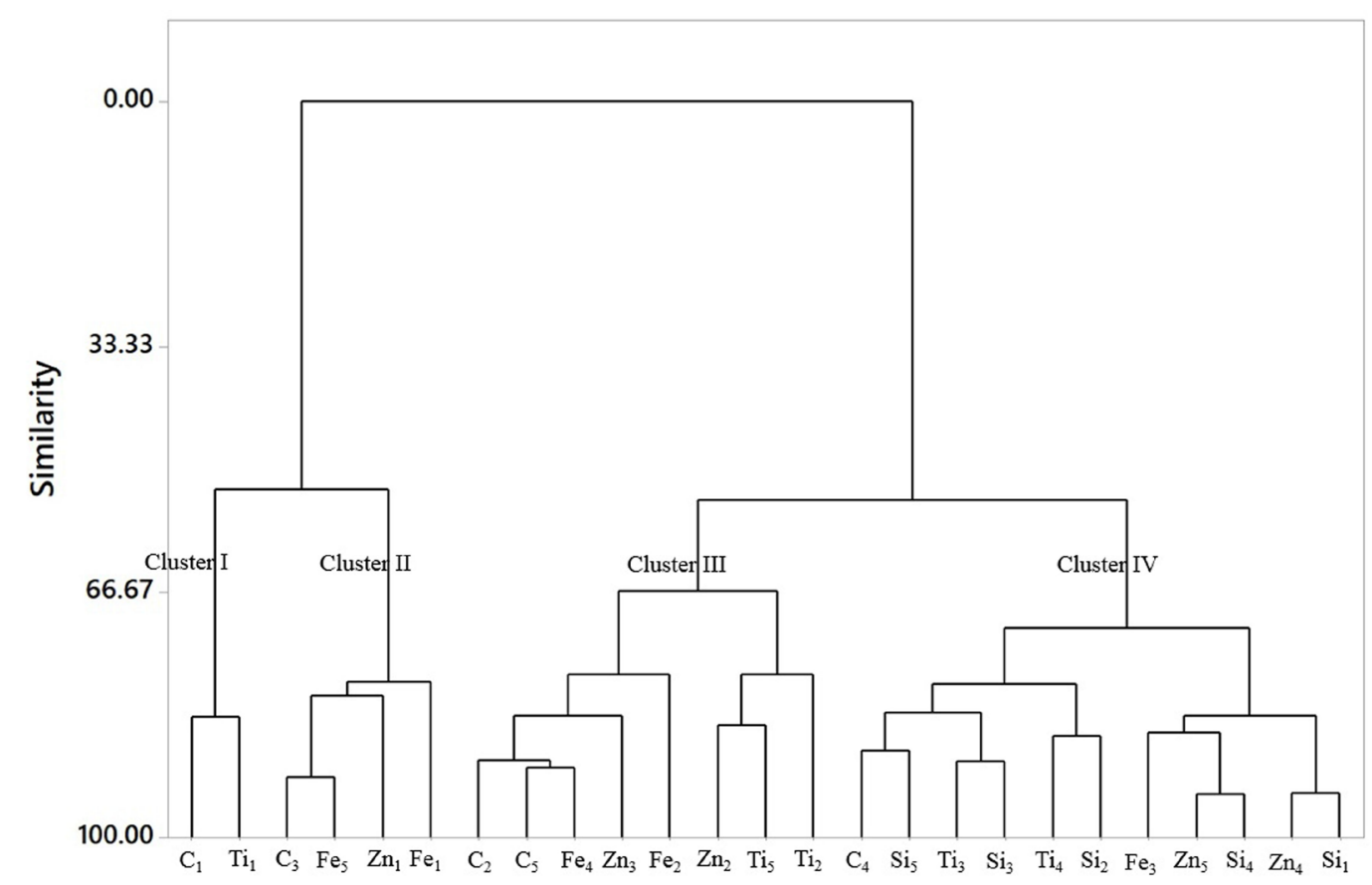

Figure 7. Cluster analysis of foliar treatments in rapeseed (Brassica napus) hybrids grown in semi-arid region of Qazvin. 1: Hydromel, 2: Neptune, 3: Nathalie, 4: Danube, 5: Alonso. The combined treatments in each cluster were somewhat similar in terms of the effect on the studied traits. 
reason, any nutritional management treatment can have significant effects on the amount of production in this area and there are widespread aspects of nutrition and production improvement. In the conventional farming method, fertilisers from an inorganic source may not protect soil structure, and they may cause variations in $\mathrm{pH}$ and ion concentrations of the soil sample (Sangeetha et al. 2017). Findings of current study relatively showed that application of nano techniques in chemical fertilisers can increase their effectiveness.

\section{CONCLUSIONS}

The results of current experiment showed that the best performance was recorded for foliar application nano- $\mathrm{TiO}_{2}(20 \mathrm{ppm}), \mathrm{Fe}$ and $\mathrm{Zn}(2,000$ ppm). This improvement could be due to increased growth stimulating hormones, increasing the effective compounds in defense systems such as proline and anthocyanins, photosynthetic pigment enhancement, improved membrane protection and ultimately increased seed yield components. These results may indicate the significant deficiency of micronutrient in studied location. Also comparison of the cultivar showed that there is significant variation between the genotypes in terms of the response to foliar treatments. Overall the best performance was recorded for cv. Hydromel. Evaluation of interaction effects of foliar treatment and cultivars indicated that application of nano- $\mathrm{SiO}_{2}$ could positively affect most of the genotypes. The lowest oxygen reactive species was recorded for cv. Neptune by application of Fe and $\mathrm{Zn}$. Nano-SiO 2 application considerably improved the membrane integrity as indicated by low MDA content in such treated plants. The highest indo lactic was recorded in cv. Neptune, and Nathalie treated with Fe, $\mathrm{Zn}$ and Ti. Altogether obtained results highlighted the importance of micronutrient fertiliser and application of nano- $\mathrm{TiO}_{2}$ in semi-arid region.

Acknowledgements. The authors are grateful to research council of University of Maragheh for financial support of this project. Also the authors would like to thank experts of Central Laboratory (depended on Laboratory Network of Strategic Technologies) for their assistance in biochemical analysis.
The authors are grateful to M. Amini for critical reading and helpful discussions on the manuscript.

\section{REFERENCES}

BATES, L.S. - WALDREN, R.P. - TEARE, I.D. 1973. Rapid determination of free proline for water stress studies. In Journal of Plant Soil, vol. 39, pp. 205-217. DOI: 10.1007/ BF00018060

COSKUN, D. - BRITTO, D.T. - HUYNH, W.Q. - KRONZUCKER, H.J. 2016. The role of silicon in higher plants under salinity and drought stress. In Frontiers in Plant Science, vol. 7:1072. DOI: $10.3389 /$ fpls.2016.01072

DAI, F. - HUANG, Y. - ZHOU, M. - ZHANG, G. 2009. The influence of cold acclimation on antioxidative enzymes and antioxidants in sensitive and tolerant barley cultivars. In Biologia Plantarum, vol. 53, no. 2, pp. 257-262. DOI: 10.1007/s10535-009-0048-5

DANILOVIČ, M. - ŠOLTYSOVÁ, B. 2010. Nutrient management analysis in field pea (Pisum sativum L.) cultivated in the no-tillage technology. In Agriculture (Polnohospodárstvo), vol. 56, no. 1, pp. 18-24.

DERE, S. - GINES, T. - SIVACI, R. 1998. Spectrophotometric determination of chlorophyll-A, B and total carotenoid contents of some algae species using different solvents. In Turkish Journal of Botany, vol. 22, no. 1, pp. 13-18. DOI:10.1.1.617.505: 10.1.1.617.505

DUBOIS, M. - GILLES, K.A. - HAMILTON, J.K. - REBES, P.A. - SMITH, F. 1956. Colorimetric method for determination of sugars and related substrates. In Analytical Chemistry, vol. 28, pp. 350-356. DOI: 10.1021/ac60111a017

FAOSTAT, 2018. Faostat Agriculture data. http://www.apps.fao. org. Accessed 06 March 2018.

GAO, F. - LIU, C. - QU, C. - ZHENG, L. - YANG, F. - SU, M. - HONG, F. 2008. Was improvement of spinach growth by nano- $\mathrm{TiO}_{2}$ treatment related to the changes of RUBISCO activase? In Biometals, vol. 21, pp. 211-217. DOI: 10.1007/ s10534-007-9110-y

GERAMI, M. - RAMEEH, V. 2012. Study of silicon and nitrogen effects on yield components and shoot ions nutrient composition in rice. In Agriculture (Polnohospodárstvo), vol. 58, no. 3, pp. 93-98. DOI: 10.2478/v10207-012-0011-x GHOLAMI-SHABANI, M. - GHOLAMI-SHABANI, Z. - SHAMS-GHAHFAROKHI, M. - JAMZIVAR, F. RAZZAGHI-ABYANEH, M. 2017. Green nanotechnology: biomimetic synthesis of metal nanoparticles using plants and their application in agriculture and forestry. In PRASAD, R. - KUMAR, M. - KUMAR, V. (Eds.). Nanotechnology: An Agricultural Paradigm. Springer Nature Singapore Pte Ltd., pp. 135-177.

GRUNWALD, C. - LOCKARD, R.G. 1970. Analysis of indole acid derivatives by gas chromatography using liquid phase OV-101. In Journal of Chromatography A, vol. 52, pp. 491-493.

HEATH, R.L. - PACKER, L. 1968. Photoperoxidation in isolated chloroplasts. I. Kinetics and stoichiometry of fatty acid peroxidation. In Archives of Biochemistry and Biophysics, vol. 125, pp. 189-198. DOI: 10.1016/0003-9861(68)90654110.1016/0003-9861(68)90654-1

JANMOHAMMADI, M. - AMANZADEH, T. - SABAGHNIA, N. - DASHTI, S. 2016. Impact of foliar application of nano micronutrient fertilizers and titanium dioxide nanoparticles on the growth and yield components of barley under supplemental irrigation. In Acta Agriculturae Slovenica, vol. 107, no. 2, pp. 265-276. DOI: 10.14720/ 
aas.2016.107.2.0110.14720/aas.2016.107.2.01

JANMOHAMMADI, M. - MOHAMADI, N. - SHEKARI, F. - ABBASI, A. - ESMAILPOUR, M. 2017. The effects of silicon and titanium on safflower (Carthamus tinctorius L.) growth under moisture deficit condition. In Acta Agriculturae Slovenica, vol. 109, no. 2, pp. 443-455. DOI: 10.14720/ aas.2017.109.2.27

LEI, Z. - MINGYU, S. - XIAO, W. - CHAO, L. - CHUNXIANG, Q. - LIANG, C. - HAO, H. - XIAOQING, L. - FASHUI, H. 2008. Antioxidant stress is promoted by nano-anatase in spinach chloroplasts under UV-B radiation. In Biological Trace Element Research, vol. 121, no. 1, pp 69-79. DOI: $10.1007 / \mathrm{s} 12011-007-8028-0$

LEI, Z.-MINGYU, S. - XIAO, W.-CHAO, L. - CHUNXIANG, Q. - LIANG, C. - FASHUI, H. 2007. Effects of nano-anatase on spectral characteristics and distribution of LHCII on the thylakoid membranes of spinach. In Biological Trace Element Research, vol. 120, no. 1-3, pp. 273-283. DOI: 10.1007/s12011-007-8025-3

LIANG, X. - ZHANG, L. - NATARAJAN, S.K. - BECKER, D.F. 2013. Proline mechanisms of stress survival. In Antioxidants \& Redox Signaling, vol. 19, no. 9, pp. 998-1011. DOI 10.1089/ars.2012.5074

LU, C.M. - ZHANG, C.Y. - WEN, J.Q. -WU, G.R. - TAO, M.X. 2002. Research on the effect of nanometer materials on germination and growth enhancement of Glycine max and its mechanism. In Soybean Science, vol. 21, no. 3, pp. $168-171$.

LUKAS, V. - RODRIGUEZ-MORENO, F. - DRYŠLOVÁ, T. - NEUDERT, L. 2014. Effectiveness of chlorophyll meter measurement in winter wheat at field scale level. In Agriculture (Pol'nohospodárstvo), vol. 60, no. 2, pp. 41-49. DOI: 10.2478/agri-2014-0005

MA, J.F. - YAMAJI, N. 2006. Silicon uptake and accumulation in higher plants. In Trends in Plant Science, vol. 11, no. 8, pp. 392-397. DOI: 10.1016/j.tplants.2006.06.007

MA, J.F. 2004. Role of silicon in enhancing the resistance of plants to biotic and abiotic stresses. In Soil Science and Plant Nutrition, vol. 50, pp. 11-18. DOI: 10.1080/00380768.2004

MA, J.F. - MIYAKE, Y. - TAKAHASHI, E. 2001. Silicon as a beneficial element for crop plants. In DATNOFF, L.E. SNYDER, G.H. - KORNDÖRFER, K.H. (Eds.). Silicon in Agriculture. New York, NY : Elsevier Science Publishing, pp. 17-39. DOI: 10.1016/S0928-3420(01)80006-9

MAHMOODZADEH, H. - NABAVI, M. - KASHEFI, H. 2013. Effect of nanoscale titanium dioxide particles on the germination and growth of canola (Brassica napus). In Journal of Ornamental and Horticultural Plants, vol. 3, pp. 25-32.

MARSCHNER, H. 2011. Marschner's mineral nutrition of higher plants. Academic press, 672p. ISBN 9780123849052

MOHAMMADI, H. - ESMAILPOUR, M. - GHERANPAYE, A. 2016. Effects of $\mathrm{TiO}_{2}$ nanoparticles and water-deficit stress on morpho-physiological characteristics of dragonhead (Dracocephalum moldavica L.) plants. In Acta Agriculturae Slovenica, vol. 107, no. 2, pp. 385-396. DOI: 0.1016/j. envexpbot.2005.12.006

PAUL, M.J. - FOYER, C.H. 2001. Sink regulation of photosynthesis. In Journal of Experimental Botany, vol. 52, pp. 1383-1400. DOI: 10.1093/jexbot/52.360.1383

PEEL, M.C. - FINLAYSON, B.L. - MCMAHON, T.A. 2007. Updated world map of the Köppen-Geiger climate classification. In Hydrology and Earth System Sciences Discussions, vol. 4, no. 2, pp. 439-473. DOI: 10.5194/hess-11$1633-2007$
RAVI, S. - CHANNAL, H.T. - HEBSUR, N.S. - PATIL, B.N. - DHARMATTI, P.R. 2008. Effect of sulphur, zinc and iron nutrition on growth, yield, nutrient uptake and quality of safflower (Carthamus tinctorius L.). In Karnataka Journal of Agricultural Sciences vol. 21, no. 3, pp. 382-385.

ROUT, G.R. - SAHOO, S. 2015. Role of iron in plant growth and metabolism. In Reviews in Agricultural Science, vol. 3, pp. 1-24. DOI: $10.7831 /$ ras.3.1

SANGEETHA, J. - THANGADURAI, D. - HOSPET, R. PURUSHOTHAM, P. - KAREKALAMMANAVAR, G. MUNDARAGI, A.C. - HARISH, E.R. 2017. Agricultural nanotechnology: concepts, benefits, and risks. In PRASAD, R. - KUMAR, M. - KUMAR, V. (Eds.). Nanotechnology. Singapore : Springer, pp. 1-17.

SHEIKHIAN, L. - BINA, S. 2016. Simultaneous extraction and HPLC determination of 3-indole butyric acid and 3-indole acetic acid in pea plant by using ionic liquid-modified silica as sorbent. In Journal of Chromatography B, vol. 1009, pp. $34-43$.

SIELING, K. - CHRISTEN, O. 2015. Crop rotation effects on yield of oilseed rape, wheat and barley and residual effects on the subsequent wheat. In Archives of Agronomy and Soil Science, vol. 61, no. 11, pp. 1531-1549.

ŠOLTYSOVÁ, B. - DANILOVIČ, M. 2011. Tillage in relation to distribution of nutrients and organic carbon in the soil. In Agriculture (Polnohospodárstvo), vol. 57, no. 1, pp. 21-30.

SUN, D. - HUSSAIN, H.I. - YI, Z. - ROOKES, J.E. - KONG, L. - CAHILL, D.M. 2016. Mesoporous silica nanoparticles enhance seedling growth and photosynthesis in wheat and lupin. In Chemosphere, vol. 152, pp. 81-91. DOI: 10.1016/j. chemosphere.2016.02.096

TADAYYON, A. - BEHESHTI, S. - PESSARAKLI, M. 2017. Effects of sprayed humic acid, iron, and zinc on quantitative and qualitative characteristics of niger plant (Guizotia abyssinica L.). In Journal of Plant Nutrition, vol. 40, no. 11, pp. 1644-1650. DOI: 10.1080/01904167.2016.1270321

THIYAM-HOLLÄNDER, U. - ESKIN, N.M. - MATTHÄUS, B. 2012. Canola and rapeseed: production, processing, food quality, and nutrition. Boca Raton, Florida, US : CRC Press, $374 \mathrm{p}$.

VAN BOCKHAVEN, J. - DE VLEESSCHAUWER, D. - HOFTE, M. 2013. Towards establishing broad-spectrum disease resistance in plants: silicon leads the way. In Journal of Experimental Botany, vol. 64, pp. 1281-1293. DOI: 10.1093/ jxb/ers 329

WANASUNDARA, J.P. - MCINTOSH, T.C. - PERERA, S. P. - WITHANA-GAMAGE, T.S. - MITRA, P. 2016. Canola/rapeseed protein-functionality and nutrition. In $O C L$, vol. 23, no. 4, D407. DOI: 10.1051/oc1/2016028 10.1051/ ocl $/ 2016028$

WANG, S. - WANG, F. - GAO, S. 2015. Foliar application with nano-silicon alleviates $\mathrm{Cd}$ toxicity in rice seedlings. In Environmental Science and Pollution Research, vol. 22, no. 4, pp. 2837-2845. DOI: 10.1007/s11356-014-3525-0

ZHANG, L. - FANG, M. 2010. Nanomaterials in pollution trace detection and environmental improvement. In Nano Today, vol. 5, pp. 128-142. DOI: 10.1016/j.nantod.2010.03.00210.1016/j.nantod.2010.03.002

ZHU, Y. - GONG, H. 2014. Beneficial effects of silicon on salt and drought tolerance in plants. In Agronomy for Sustainable Development, vol. 34, pp. 455-472. DOI: 10.1007/ s13593-013-0194-1

Received: March 13, 2018 